\title{
Magnetic fabric of the Parashi stock and related dyke swarm, Alta Guajira (Colombia): The Caribbean-South American plates oblique convergence
}

\author{
*Camilo Bustamante ${ }^{1}$, Carlos J. Archanjo² ${ }^{2}$ Agustín Cardona $^{3}$, Marcela Restrepo ${ }^{1}$
}

\author{
1 Departamento de Ciencias de la Tierra, Universidad EAFIT, Carrera 49 No. 7 Sur-50, Medellín, Colombia. \\ cbustam3@eafit.edu.co,marest56@eafit.edu.co \\ 2 Instituto de Geociências, Universidade de São Paulo, Rua do Lago 562, CEP 05508-080, São Paulo, Brasil. \\ archan@usp.br \\ 3 Departamento de Procesos y Energía, Facultad de Minas, Universidad Nacional, Carrera 80, 65-223, Medellín, Colombia. \\ agcardonamo@unal.edu.co
}

* Corresponding author: cbustam3@eafit.edu.co

\begin{abstract}
Anisotropy of magnetic susceptibility (AMS) and anhysteretic remanence (AAR) were used to evaluate the emplacement history of the Parashi stock and related dyke swarm situated in NW Colombia. The average magnetic susceptibility of $4.5 \times 10^{-2} \mathrm{SI}$, in conjunction with low-coercivity components provided by the isothermal remanence and thermomagnetic curves with net Verwey and Curie transitions, indicates that multidomain magnetite records the anisotropy directions. The similar orientation and shape of the AMS and AAR ellipsoids indicate the absence of very fine magnetite with an inverse fabric. The magnetic foliation is the best-defined fabric element in these rocks and outlines a concentric structure, elongated parallel to the NE-SW direction of the pluton. Crystallisation age of the stock and dykes (51-47 Ma), along with pressure of emplacement determination indicate that the stock and the dyke swarm probably formed simultaneously, and they were emplaced in the shallow crust $(<10 \mathrm{~km})$. The magnetic fabric agrees with emplacement in a transtensional setting, with the dyke swarm infilling tensional cracks formed during the final stages of pluton crystallisation. This tectonic setting likely records the difficulty of the thick oceanic crust subducting, which would result in general transtension in the overriding continental plate and cessation of arc magmatism in the Eocene.
\end{abstract}

Keywords: AMS, Petrofabric, Pluton emplacement, Parashi stock, Caribbean plate.

RESUMEN. Fábrica magnética del stock de Parashi y el enjambre de diques relacionado, Alta Guajira (Colombia): la convergencia oblicua entre las placas del Caribe y Sudamericana. Se utilizó Anisotropía de Susceptibilidad Magnética (ASM) y Remanencia Anisterética (ARA) para evaluar la historia de emplazamiento del stock Parashi y del enjambre de diques relacionados situados en el noroeste de Colombia. La susceptibilidad magnética promedio de $4,5 \times 10^{-2} \mathrm{SI}$, junto con los componentes de baja coercitividad proporcionados por la remanencia isotérmica y las curvas termomagnéticas con las transiciones de Verwey y Curie, indican que la magnetita multidominio registra las direcciones de anisotropía. Las orientaciones y formas similares de los elipsoides ASM y ARA sugieren la ausencia de magnetita muy fina con una fábrica inversa. La foliación magnética es el elemento de la fábrica mejor definido en estas rocas y determina una estructura concéntrica, alargada paralela a la dirección NE-SO del plutón. La edad de cristalización del stock y los diques (51-47 Ma), junto con los cálculos de presión de emplazamiento, indican que el stock y el enjambre de diques probablemente se formaron simultáneamente y se emplazaron en la corteza poco profunda $(<10 \mathrm{~km})$. La fábrica magnética concuerda con el emplazamiento en un régimen transtensional y con el enjambre de diques que rellena las fracturas tensionales formadas durante las etapas finales de la cristalización del plutón. Este escenario tectónico probablemente registra la dificultad de subducción de la corteza oceánica gruesa, lo que resultaría en una transtensión general en la placa continental y el cese del magmatismo de arco en el Eoceno. 


\section{Introduction}

Low-field Anisotropy of Magnetic Susceptibility (AMS) is a useful technique for recording fabrics in rocks that appear isotropic by visual inspection. This anisotropy is based on the difference between the magnetic susceptibility measured in different directions of the rock, which itself depends on the preferred orientation of all the mineral grains weighted according to their concentrations and grain anisotropies (Hrouda, 1982). In granitic rocks, AMS records the bulk contribution of the diamagnetic (quartz, feldspars), paramagnetic (micas, amphibole) and ferromagnetic (magnetite, hematite) mineral assemblages. The relationship between AMS and magmatic fabrics in plutons, irrespective of the paramagnetic and/or ferromagnetic source of the AMS, has been widely used to investigate emplacement mechanisms and relationships with regional tectonic processes (Archanjo et al., 1994; Cruden, 1998; Siegesmund and Becker, 2000; Clemens and Benn, 2010; Trubac et al., 2014; Mamtani et al., 2019).

The Anisotropy of Anhysteretic Remanence (AAR) is a complementary magnetic method that records only the contribution to the magnetic fabric of minerals carrying a remanence, which is mostly magnetite in granitic rocks (Jackson, 1991). Like AMS, AAR can also be represented as a second-rank tensor, with the principal directions represented by an ellipsoid. The AMS and AAR data, therefore, can provide valuable information about emplacement tectonics at different stages of pluton construction (Bouchez, 1997), especially in volcano-plutonic complexes in which earlier intrusions are often later invaded, usually in the shallower crust, by subvolcanic rocks and dykes (e.g., Magee et al., 2012; Tomek et al., 2017; Burton-Johnson et al., 2019).

In this contribution, AMS and AAR fabric data have been used to evaluate the emplacement mechanisms of a shallow quartz diorite stock, intruded by andesitic to dacitic dykes, situated in the Guajira Península of northern Colombia. A Late Cretaceous to Eocene magmatic arc is present along the Andes, from Ecuador to the Caribbean margin of Colombia and Venezuela. This is related to the oblique subduction of the Caribbean oceanic plate beneath the northern edge of the South American plate (Fig. 1; Pindell et al., 2005; Hughes and Pilatasig, 2002; Vallejo et al., 2006; Pindell and Kennan, 2009; Bustamante et al., 2009; Cardona et al., 2011a, b; Weber et al., 2010;
Montes et al., 2019). The Parashi stock and dykes intrude Cretaceous accretionary complexes associated with a former arc-continent collision (Cardona et al., 2009; Weber et al., 2009, 2010; Montes et al., 2019) and constitute one of the latest records of Eocene magmatism in Colombia (Cardona et al., 2014). This study examines the magnetic fabric of a quartz-dioritic stock and related dyke swarm from a time when the oblique convergence of the Caribbean plate triggered the exhumation and disruption of the former Late Cretaceous collisional orogen in the Guajira region.

\section{Geologic setting}

The Late Cretaceous to Paleogene tectonic evolution of northwestern Andean Cordillera and northern South American-Caribbean region has been related to the interaction between the Caribbean plate, as it migrated from a southwestern Pacific position, and the continental margin of South America (Burke et al., 1984; Lugo and Mann, 1995; Kerr et al., 1997; Pindell et al., 1998, 2005; Pindell and Keenan, 2009; Boschman et al., 2014; Montes et al., 2019). The continuous oblique convergence between the two tectonic plates is responsible for major block displacements and the formation of Cenozoic basins in northernmost Colombia and Venezuela (Duque-Caro, 1979; Muessig, 1984; Macellari, 1995; Montes et al., 2010). The subsequent subduction of the Caribbean plate beneath the South American continental margin is responsible for the formation of a short-lived Paleocene-Eocene magmatic arc (Cardona et al., 2011b, 2014; Bayona et al., 2012; Bustamante et al., 2017). The oblique nature of the Caribbean-South American plates interactions has been inferred mainly from palaeogeographic reconstructions, including palaeomagnetic evidences of block rotation, lithotectonic correlation and basin filling histories (Escalona and Mann, 2003; Pindell and Keenan, 2009; Montes et al., 2010, 2019; Boschman et al., 2014; Nova et al., 2019).

The Palaeogene magmatic arcs formed in continental and oceanic domains that resulted from the Caribbean convergence, are exposed in the Central and Western Cordilleras of Colombia (Cardona et al., 2018). In the Central Cordillera, the magmatism lasted from $\sim 60$ to $45 \mathrm{Ma}$, and the related plutonic rocks intruded a thickened continental margin that grew as a consequence of the former Caribbean- 


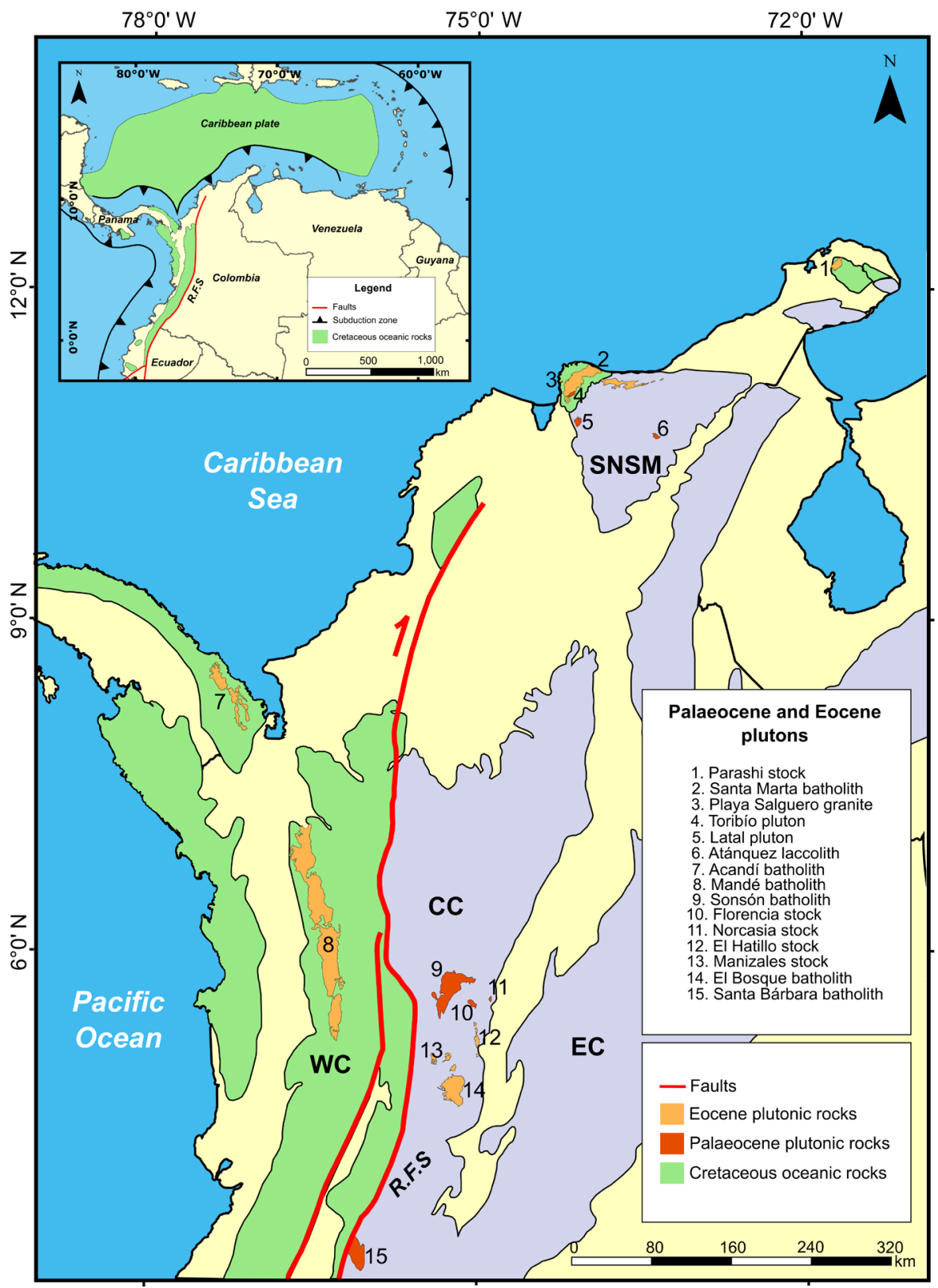

FIG. 1. Regional map showing the current tectonic context of the Caribbean (inset). The subduction zones of the Antilles (east) and Panama (west), and strike-slip faults to the north and south, are limits of this plate. Accreted oceanic terranes related to the oblique subduction of the Caribbean plate beneath northwestern South America crops out along western Colombia, Ecuador and Panama, to the west of the Romeral Fault System (R.F.S). The larger map is showing the Cretaceous oceanic rocks of the West Cordillera (WC) in contact with the Central Cordillera (CC) along the Romeral Fault System (R.F.S). Plutonic rocks indicated with numbers corresponds to the Palaeocene-Eocene magmatic arc. EC: Eastern Cordillera; SNSM: Sierra Nevada de Santa Marta (modified from Bayona et al., 2012; Kerr, 2014 and Salazar et al., 2016).

South American plate collision (Bayona et al., 2013; Bustamante et al., 2017; Cardona et al., 2018; DuqueTrujillo et al., 2019a). In the Western Cordillera, the volcanic and plutonic complexes formed from $71 \mathrm{Ma}$ to $34 \mathrm{Ma}$ and probably intrude remnants of an Early Cretaceous oceanic plateau (Cardona et al., 2018). 
Farther north in the Caribbean region (Sierra Nevada de Santa Marta, Guajira Peninsula), the magmatic rocks intruded subduction- and/or collisional-related complexes (Weber et al., 2009, 2010; Cardona et al., 2010). One of these collisional complexes is the Late Cretaceous Etpana Formation that crops out on the northwestern part of the Guajira Península (Fig. 2) and comprises low-grade greenschists, phyllites and quartzites, and some intercalated serpentinites, rodingites and gabbros (Lockwood, 1965; Weber et al., 2010). Lockwood (1965) describes the foliation in the Etpana Formation as defined by a weak cleavage that is usually oriented parallel to bedding and with nearly E-W trending folds developed in the southern portions of the formation and superimposed on N-S folds developed north and east of the Parashi stock (Fig. 2).

Among the most studied Paleogene plutons of the Caribbean region are the Santa Marta batholith and the
Parashi stock (Cardona et al., 2011b, 2014; Salazar et al., 2016; Duque-Trujillo et al., 2019b). The former corresponds to the largest Eocene pluton in Colombia, whereas the Parashi stock and sub-volcanic rocks found in well-logs near the Paraguana Península in Venezuela mark the northeastern end of the Eocene magmatism (Bayona et al., 2012; Bustamante et al., 2017; Baquero et al., 2014). The absence of post-Eocene magmatic rocks is likely due to the difficulty of the thick oceanic plateau to subduct combined with the more oblique nature of the Caribbean-South American plates convergence (Bayona et al., 2012; Cardona et al., 2014; Montes et al., 2019).

The Santa Marta batholith consists of granodiorites and tonalites, dated between 58 and $54 \mathrm{Ma}(\mathrm{U}-\mathrm{Pb}$ in zircons), which are followed by small volume of felsic pulses emplaced between 52 and $50 \mathrm{Ma}$ (Cardona et al., 2011b; Salazar et al., 2016; DuqueTrujillo et al., 2019b). The AMS and AAR results

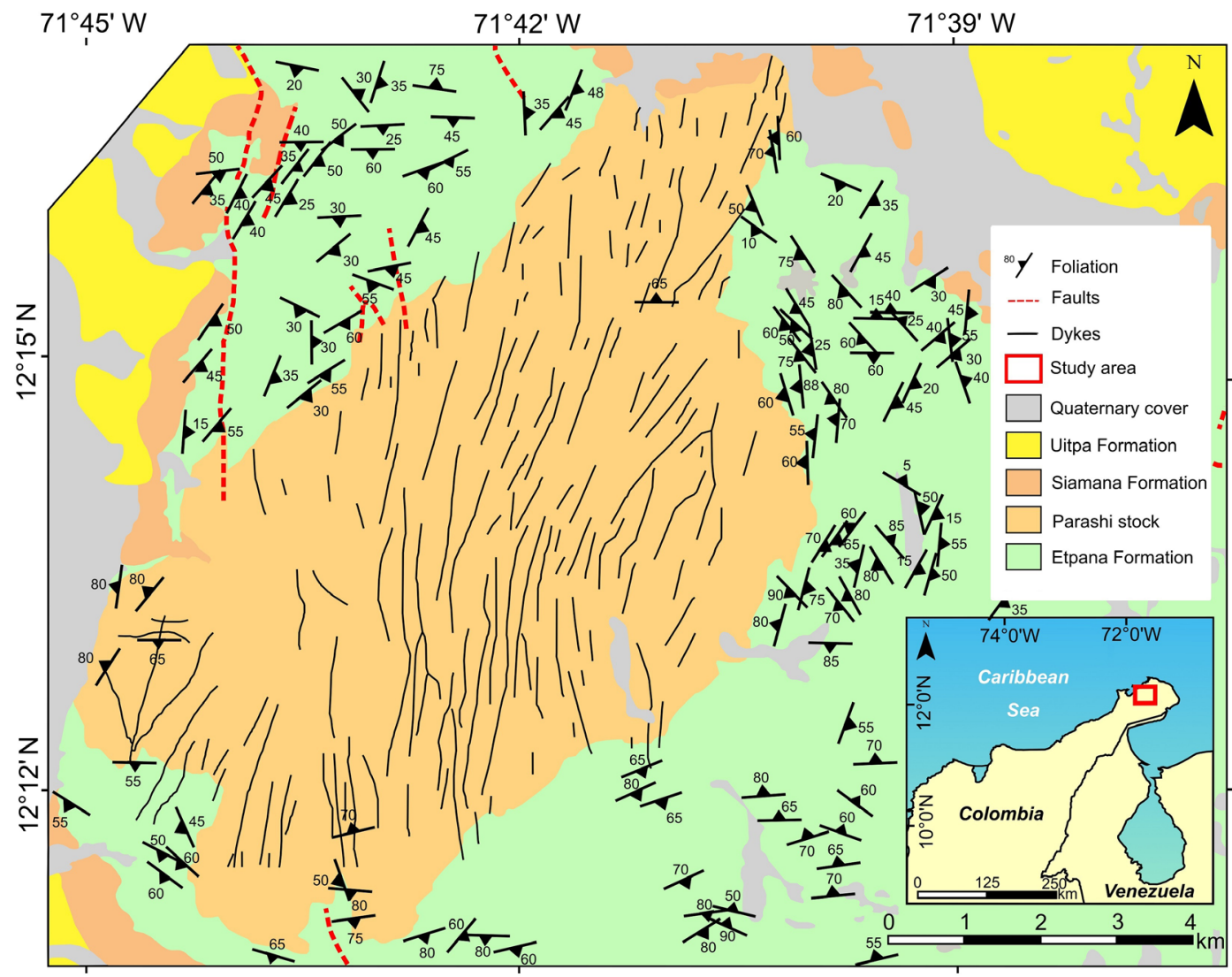

FIG. 2. Geological map showing the location of the Parashi stock, the trend of the dyke swarm and the foliations of the country rock (After Lockwood, 1965). 
from the Santa Marta batholith have been interpreted to record a transpressive arc setting related to the compression and lateral migration of the Caribbean plate (Salazar et al., 2016). The Parashi stock (about $56 \mathrm{~km}^{2}$; Fig. 2), in turn, is located to the northeast of the Santa Marta batholith in the Jarara Serranía of the Guajira Península. It is surrounded by middle Tertiary marine limestones and shales of the Uitpa and Siamana formations (Fig. 2) and consists of a quartz diorite to granodiorite body with biotite and hornblende that is partially covered unconformably by Oligo-Miocene conglomerate and carbonate rocks (Lockwood, 1965; Zapata et al., 2010). The stock includes a swarm of $\mathrm{N}$ - to NE-trending andesitic to dacitic dykes, and all these rocks intrude lowgrade metapelites and the metaultramafic rocks of the Etpana Formation (Fig. 2). A thermal aureole of approximately $50 \mathrm{~m}$ in width has been described in the metapelites around the Parashi stock. These rocks reached the hornblende-hornfels facies, as attested to by the presence of andalusite crystals set in a matrix of quartz, biotite and oligoclase, which is shown to be replacing a former lower-temperature assemblage containing sericite, chlorite, quartz and albite (Lockwood, 1965; Martínez and Zuluaga, 2010; Weber et al., 2010). Both the pluton and the dykes yielded zircon $\mathrm{U}-\mathrm{Pb}$ crystallisation ages between 51 and $47 \mathrm{Ma}$ which, in turn, overlaps with the late crystallisation phases of the Santa Marta Batholith (Cardona et al., 2014).

\section{Methods}

\subsection{Sampling and sample preparation}

We collected samples from 13 sites in the Parashi stock and 11 sites from different dykes. The relatively few samples collected in the pluton and dykes are related to poor exposure of the rocks in the Guajira region as well as the limited access due to the few roads available. For the magnetic studies, we drilled 2 or 3 oriented rock cores of one-inch diameter using a portable gasoline-powered drill. In the laboratory, the cores were sliced into $2.2 \mathrm{~cm}$ long specimens, providing between 5 and 8 specimens per site in both pluton and dykes. A total of 84 specimens for the stock and 67 specimens for the dykes were studied by both AMS and AAR methods in the Laboratório de Paleomagnetismo at the University of São Paulo, Brazil.

\subsection{Anisotropy of magnetic susceptibility}

Low-field AMS was measured on an MFK1FA Kappabridge (200 A/m, AC field at $920 \mathrm{~Hz}$ ), and the AMS tensor was calculated using Jelinek statistics (Jelinek, 1978) through ANISOFT software provided by the equipment manufacturer (AGICO). The calculated AMS parameters are the principal directions of the ellipsoid tensor $\left(\mathrm{k}_{1} \geq \mathrm{k}_{2} \geq \mathrm{k}_{3}\right)$, the mean susceptibility $\left(\mathrm{k}_{\mathrm{m}}=\left(\mathrm{k}_{1}+\mathrm{k}_{2}+\mathrm{k}_{3}\right) / 3\right)$, the anisotropy degree $\left(\mathrm{P}=\mathrm{k}_{1} / \mathrm{k}_{3}\right)$ and the ellipsoid shape $\left(\mathrm{T}=\left[2 \ln \left(\mathrm{k}_{1} / \mathrm{k}_{1}\right) /\left(\mathrm{k}_{2} / \mathrm{k}_{3}\right)\right]-1\right)$, such that $-1 \leq \mathrm{T}<0$ for prolate and $0<\mathrm{T} \leq 1$ for oblate ellipsoids. The AMS results are shown in table 1.

\subsection{Anisotropy of anhysteretic remanence}

The AAR technique allows to analyse the (ferro)magnetic phases that contribute to the remanence. The method consists of inducing an anhysteretic magnetization in different orientations of the specimen and measuring the respective remanence in each orientation (see details in McCabe et al., 1985 and Jackson, 1991). The resulting anisotropy of anhysteretic remanence tensor can be described by an ellipsoid and then compared to the AMS results. This approach is particularly useful in detecting sub-fabrics (Jackson, 1991; Borradaile and Jackson, 2004) and the eventual contribution of very fine-seized magnetic particles in the rock that may provide inverse magnetic fabrics (Stephenson et al., 1986; Rochette et al., 1992). The magnitude, shape and principal directions of the AAR tensor were determined with ANISOFT software.

Coercivity allows estimating the size of the ferromagnetic minerals due to the dependence of the Anhysteretic Remanent Magnetization (ARM) on the grain size (Jackson et al., 1988). The coercivity spectrum is determined by demagnetising the specimen in a peak AC field of $100 \mathrm{mT}$, whereas a steady anhysteretic DC field is applied between two chosen intervals of a decaying AF peak (see details in Jackson et al., 1988). The alternating field coupled with a steady anhysteretic direct field was applied by a demagnetizer (LDA) from AGICO and the remanent magnetization measured in a JR5 magnetometer. The coercivity spectra were studied at five sites of the stock and five for the dykes. 
TABLE 1. AMS PARAMETERS OF THE PARASHI STOCK AND DYKES.

\begin{tabular}{|c|c|c|c|c|c|c|c|c|c|c|}
\hline Site & Location* & $\mathbf{K m}$ & $\mathbf{P}$ & $\mathbf{T}$ & K1dec & K1inc & K2dec & K2inc & K3dec & K3inc \\
\hline & \multicolumn{10}{|c|}{ Pluton } \\
\hline CP11 & N12 1522.8 W71 4154.8 & 52,712 & 1.12 & -0.02 & 83 & 13 & 260 & 76 & 276 & 3 \\
\hline CP12-2 & N12 1648.2 W71 4033.3 & 50,576 & 1.07 & 0.67 & 200 & 29 & 223 & 46 & 167 & 24 \\
\hline CP13 & N12 1632.2 W71 4027.9 & 52,425 & 1.11 & 0.44 & 183 & 79 & 175 & 6 & 162 & 9 \\
\hline CP14 & N12 1558.1 W71 4030.3 & 56,383 & 1.10 & 0.59 & 159 & 30 & 255 & 59 & 129 & 4 \\
\hline CP15 & N12 1524.8 W71 4049.9 & 43,787 & 1.18 & 0.61 & 287 & 14 & 71 & 62 & 218 & 21 \\
\hline CP16 & N12 1503.9 W71 4050.6 & 49,093 & 1.19 & 0.68 & 292 & 49 & 103 & 40 & 130 & 7 \\
\hline CP20 & N12 1616.7 W71 4113.5 & 56,981 & 1.11 & 0.47 & 217 & 37 & 95 & 52 & 192 & 5 \\
\hline CP22 & N12 1500.2 W71 4124.6 & 47,095 & 1.17 & 0.53 & 89 & 55 & 309 & 28 & 208 & 18 \\
\hline CP24 & N12 1340.9 W71 4321.6 & 25,069 & 1.20 & 0.47 & 138 & 14 & 284 & 57 & 197 & 29 \\
\hline CP25 & N12 1324.1 W71 4407.6 & 49,232 & 1.17 & 0.73 & 59 & 56 & 211 & 31 & 306 & 9 \\
\hline CP26 & N12 1354.0 W71 4339.2 & 31,151 & 1.18 & 0.67 & 87 & 37 & 194 & 48 & 310 & 11 \\
\hline CP7 & N12 1333.1 W71 4045.6 & 30,289 & 1.15 & 0.53 & 121 & 46 & 101 & 17 & 287 & 37 \\
\hline CP8 & N12 1336.8 W71 4032.7 & 30,612 & 1.12 & 0.68 & 38 & 42 & 161 & 33 & 278 & 28 \\
\hline \multirow[t]{2}{*}{ CP9 } & N12 1428.2 W71 4015.0 & 40,147 & 1.20 & 0.63 & 242 & 6 & 224 & 15 & 44 & 74 \\
\hline & \multicolumn{10}{|c|}{ Dykes } \\
\hline CP1 & N12 1518.1 W71 4231.8 & 8,371 & 1.02 & -0.07 & 341 & 30 & 145 & 58 & 217 & 7 \\
\hline CP10 & N12 1447.8 W71 4051.8 & 10,242 & 1.06 & 0.03 & 242 & 42 & 49 & 47 & 171 & 8 \\
\hline CP12-1 & N12 1648.2 W71 4033.3 & 22,569 & 1.04 & -0.52 & 211 & 32 & 220 & 27 & 168 & 43 \\
\hline CP17 & N12 1341.2 W71 4154.3 & 3,025 & 1.03 & 0.56 & 180 & 38 & 70 & 49 & 308 & 12 \\
\hline CP18 & N12 1436.0 W71 4101.4 & 7,219 & 1.03 & -0.04 & 235 & 22 & 340 & 35 & 119 & 47 \\
\hline CP19 & N12 1650.9 W71 4106.0 & 34,161 & 1.04 & 0.15 & 131 & 49 & 121 & 22 & 248 & 25 \\
\hline CP21 & N12 1532.5 W71 4124.8 & 13,420 & 1.02 & 0.01 & 98 & 48 & 58 & 11 & 266 & 40 \\
\hline $\mathrm{CP} 23$ & N12 1353.2 W71 4306.1 & 11,979 & 1.09 & 0.34 & 165 & 9 & 221 & 69 & 21 & 17 \\
\hline CP3 & N12 1449.6 W71 4202.5 & 7,820 & 1.05 & 0.29 & 295 & 17 & 192 & 38 & 44 & 46 \\
\hline CP4 & N12 1421.8 W71 4210.3 & 4,971 & 1.03 & -0.06 & 51 & 24 & 234 & 56 & 190 & 19 \\
\hline CP5 & N12 1412.2 W71 4102.9 & 14,529 & 1.03 & 0.04 & 252 & 55 & 76 & 16 & 105 & 30 \\
\hline CP6 & N12 1350.7 W71 4053.9 & 5,506 & 1.04 & 0.26 & 73 & 17 & 195 & 69 & 194 & 12 \\
\hline
\end{tabular}

*Bogotá coordinate system.

km: mean susceptibility; P: degree of anisotropy; T: shape of the AMS ellipsoid; K1 and K3: magnetic lineation and foliation (inclination: inc and declination: dec) respectively.

\subsection{Magnetic mineralogy}

The magnetic mineralogy was investigated through the temperature dependence of the magnetic susceptibility (k-T). Representative samples of the stock were crushed to a fine sand size and the susceptibility of a small volume fraction measured from -200 to $700{ }^{\circ} \mathrm{C}$ using a CS-3/CSL furnace attached to the KLY-4 Kappabridge. At low temperatures, the susceptibility was recorded by warming the sample from $-200{ }^{\circ} \mathrm{C}$ to room temperature. From room temperature up to $700{ }^{\circ} \mathrm{C}$ (heating cycle) and back (cooling cycle), k-T was measured in an argon environment to prevent the oxidation of the sample from atmospheric oxygen during the heating/cooling cycle. 


\section{Results}

\subsection{Rock textures and microstructures}

Thin sections of every AMS site were analysed in order to identify the mineral textures that could be related to the magnetic information. Petrographic analyses performed on the Parashi stock (Lockwood, 1965; Cardona et al., 2014) show that the pluton is relatively homogeneous in composition, varying dominantly from quartz diorite to, locally, granodiorite. The texture in thin-section is typically allotriomorphic, where plagioclase and quartz compose $\sim 70 \%-80 \%$ and K-feldspar commonly less than 5\% of the rock. Ferromagnesian minerals consist mostly of hornblende and biotite, and these make up $\sim 20 \%$ of the rock. Accessory minerals include zircon, apatite, sphene, allanite and opaque minerals.

Although characterised by medium- to coarsegrained typically magmatic textures, the microstructures of the Parashi stock record widespread internal deformation, such as elongate recrystallised aggregates of quartz, deformation twins in plagioclase, the development of myrmekite and microcline twinning. Furthermore, chessboard quartz crystals often with highly sutured grain boundaries evidence that the deformation occured at high temperature (Vernon, 2000). As the host metabasic rocks usually show lowgrade metamorphic conditions (Weber et al., 2010), we consider that the internal deformation of the pluton mineral assemblage was acquired at the latest stages of magmatic crystallisation and/or just after its full crystallisation but still at high temperature.

Dykes are mainly dacite-phyric in composition and trend to $\mathrm{N}$ - to NE-direction. Euhedral phenocrysts of plagioclase and quartz are settled in a finer quartzfeldspathic matrix that includes biotite and hornblende. Ferromagnesian minerals show a preferred orientation, visible in sections parallel to the long axis of the amphiboles and/or perpendicular to the basal plane of biotite grains (Fig. 3). The mineral lineation defined by the preferred orientation of the amphiboles $\left(320^{\circ}\right.$, $40^{\circ}$ ) are usually consistent with the orientation of the magnetic lineation.

\subsection{Susceptibility and magnetic mineralogy}

Mean susceptibility $\left(\mathrm{k}_{\mathrm{m}}\right)$ values of the Parashi stock are very high, ranging from $24 \times 10^{-3}$ to $64 \times 10^{-3} \mathrm{SI}$, with an average of $45 \times 10^{-3}$ SI $(45 \mathrm{mSI})$, whereas the mean anisotropy degree $(\mathrm{P})$ varies from 1.09 to 1.22 (Fig. 4). The dykes also show high $\mathrm{k}_{\mathrm{m}}$ values, ranging from 2.11 to $37.8 \mathrm{mSI}$ (with a mean of 11.6 $\mathrm{mSI}$ ), and the dykes degree of anisotropy ranges from 1.01 to 1.10 (Fig. 4). The AMS ellipsoids are mainly oblate (Fig. 4; 91\% of the specimens have $\mathrm{T}>0.2$ ), though a few specimens display a neutral shape (Fig. $4 ;-0.2<\mathrm{T}<0.2$ in $8 \%$ of the specimens). The dykes have ellipsoids that vary from oblate to prolate (Fig. 4), although most of the ellipsoids (47\%) show neutral shapes.

The k-T curves of the Parashi stock display a net Verwey transition around $-150{ }^{\circ} \mathrm{C}$ and a strong drop of susceptibility on heating close to $580{ }^{\circ} \mathrm{C}$ (Fig. 5). On cooling, the curve is nearly reversible, indicating that none, minor new phases were formed in the experiment during the heating cycle. The coercivity spectra of the granitic rocks are similar to each other (Fig. 5) with a peak of coercivity at $10 \mathrm{mT}$ that practically vanishes after $30 \mathrm{mT}$. These results, combined with the $\mathrm{k}-\mathrm{T}$ curves, indicate that a coarse, low coercive, Ti-poor magnetite dominates the susceptibility and anisotropy of the Parashi stock.

The k-T curves of the dykes show the distinct Verwey transition and Curie temperature of Tipoor magnetite, although some samples record some differences compared to the pluton. During the heating cycle between $\sim 150$ and $250{ }^{\circ} \mathrm{C}$, the curve displays a sinuous appearance (Fig. 5), which suggests a phase transition between 200 and 300 ${ }^{\circ} \mathrm{C}$ of and oxidised magnetite (maghemite) and/ or hematite (Gehring et al., 2009) as evidenced, in addition, by the irreversibility of the susceptibility values upon cooling. However, hematite, which has a Morin transition at $-10^{\circ} \mathrm{C}$ and a Néel temperature at $670{ }^{\circ} \mathrm{C}$, was not recorded in the $\mathrm{k}$-T experiments. The coercivity spectrum of the dyke samples also decrease after a remanence peak at $10 \mathrm{mT}$. However, for samples with the lowest susceptibilities, the remanence decreases progressively and is not fully removed at $100 \mathrm{mT}$ (Fig. 5). This indicates that these samples contain, in addition to low coercive magnetite, some high coercive fraction probably corresponding to fine-grained magnetite and hematite.

\subsection{Magnetic fabric}

The k-T and coercivity spectra indicate that coarse Ti-poor magnetite carries the magnetic anisotropy of the pluton and dykes. Accordingly, 

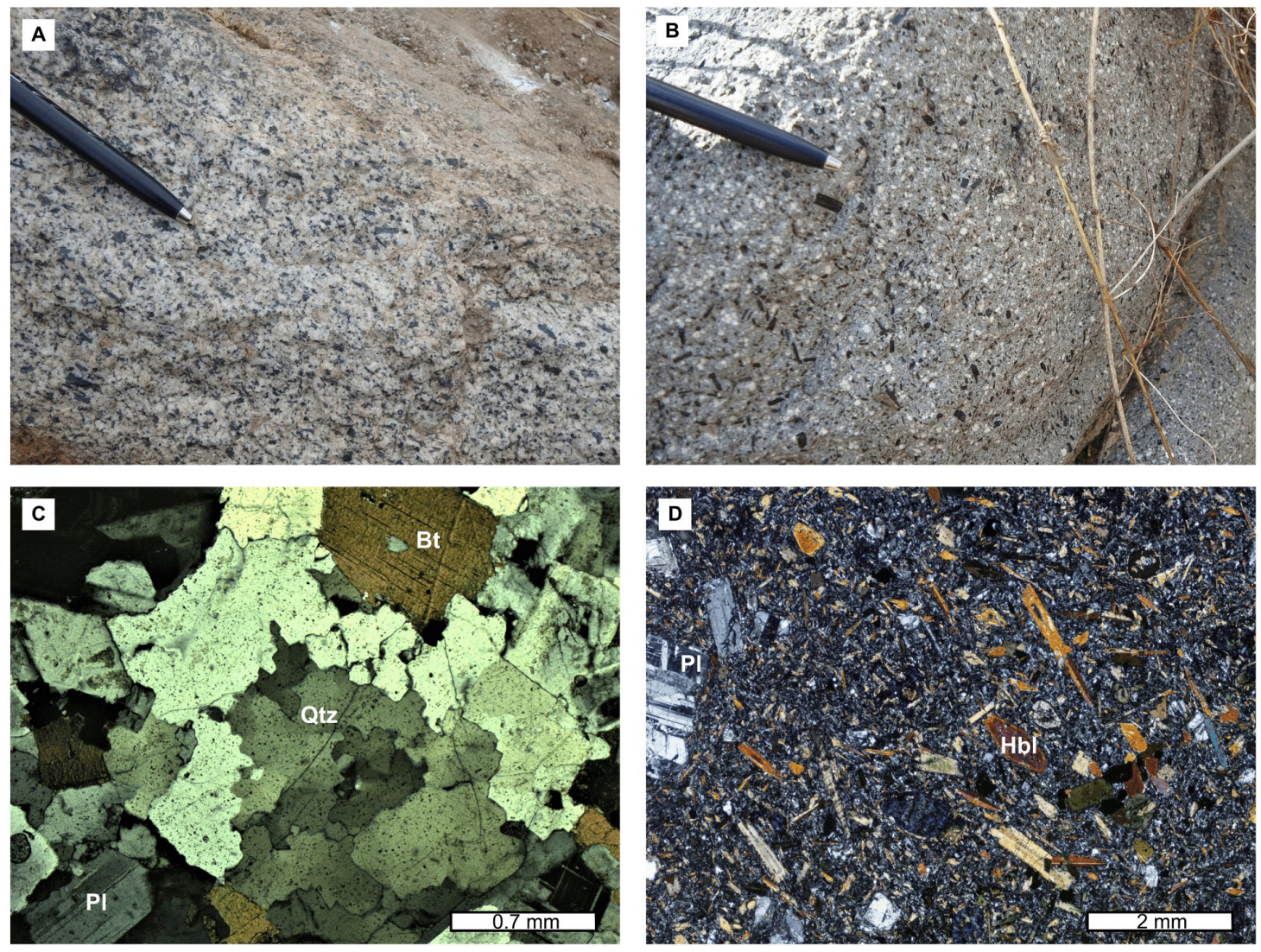

FIG. 3. Representative macrostructures of the (A) Parashi stock, showing oriented amphibole crystals that define the foliation; and (B) dykes with plagioclase and tabular amphibole phenocrysts in a quartz-feldspathic matrix. Microstructures in the (C) Parashi stock shows sutured boundaries and undulatory extinction in quartz, and kink bands in biotite; and (D) the dykes show subtle aligned hornblende crystals in a microcrystalline matrix.

although the AAR is slightly higher than the AMS in both the stock and the dykes, AMS and AAR scalar parameters are similar to each other, including their respective principal directions (Fig. 6).

Some differences, however, are recorded in the AMS parameters of the stock and dykes, such as the higher mean susceptibility and degree of anisotropy of the pluton (Fig. 6). In addition, the AMS ellipsoid shapes are dominantly oblate in the pluton and vary from oblate to prolate in the dykes (Fig. 4). Therefore, the magnetic foliation is the best-defined fabric element recorded in the pluton.

The AMS and AAR foliations (defined as perpendicular to the $\mathrm{k}_{3}$ axes) in the pluton tend to be parallel to the west and east contacts with the wall rocks and highly oblique to perpendicular to the pluton contacts in its northern part (Fig. 7). If the magnetic foliations and the planar structures measured in the field (Fig. 7) are combined, a net concentric foliation with moderate to steep dips emerges for the pluton. Magnetic lineation $\left(\mathrm{k}_{1}\right)$, in turn, show a more organised NE trend with a moderate to steep plunge, although some E-trending lineation are evident in the northern part of the intrusion (Fig. 7).

Dykes yield fabrics that can be classified as normal type, i.e., with magnetic foliation parallel to slightly oblique to the dyke margin (Rochette, 1987). However, two dykes (CP3 and CP23) show an inverse-type fabric in that both the foliation and lineation are nearly perpendicular to the dyke plane (Fig. 8). Nevertheless, as the respective AMS and AAR principal directions are coaxial (Fig. 6), the presence of very fine, singledomain magnetite that produce anomalous fabric types can be discarded (Rochette, 1987). 

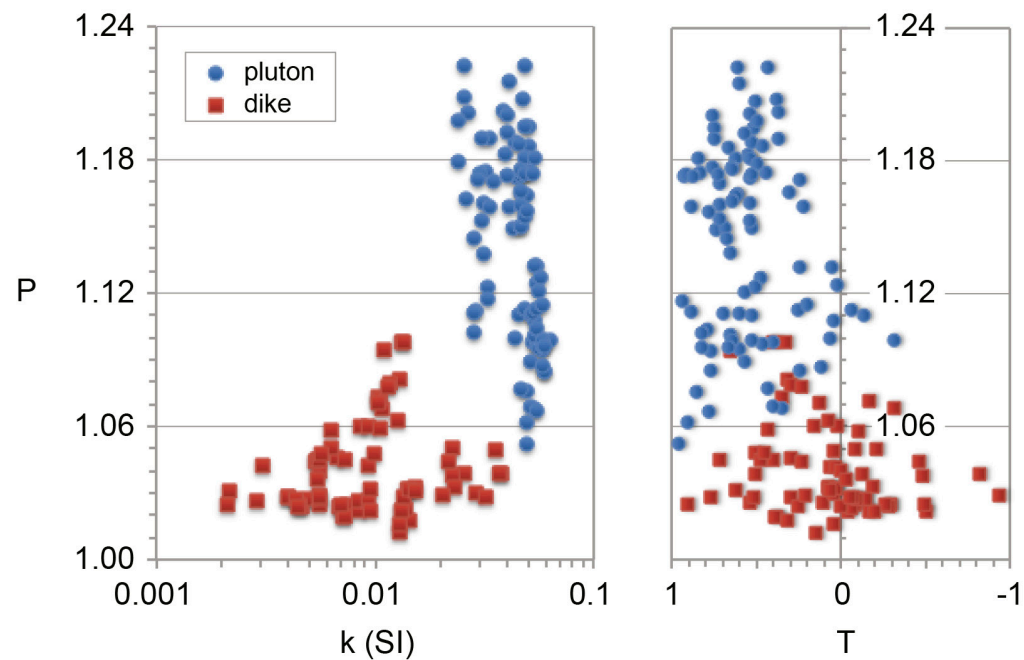

FIG. 4. Relation between the mean site magnetic susceptibility (k), the degree of anisotropy (P) and the shape (T) of the AMS ellipsoid.
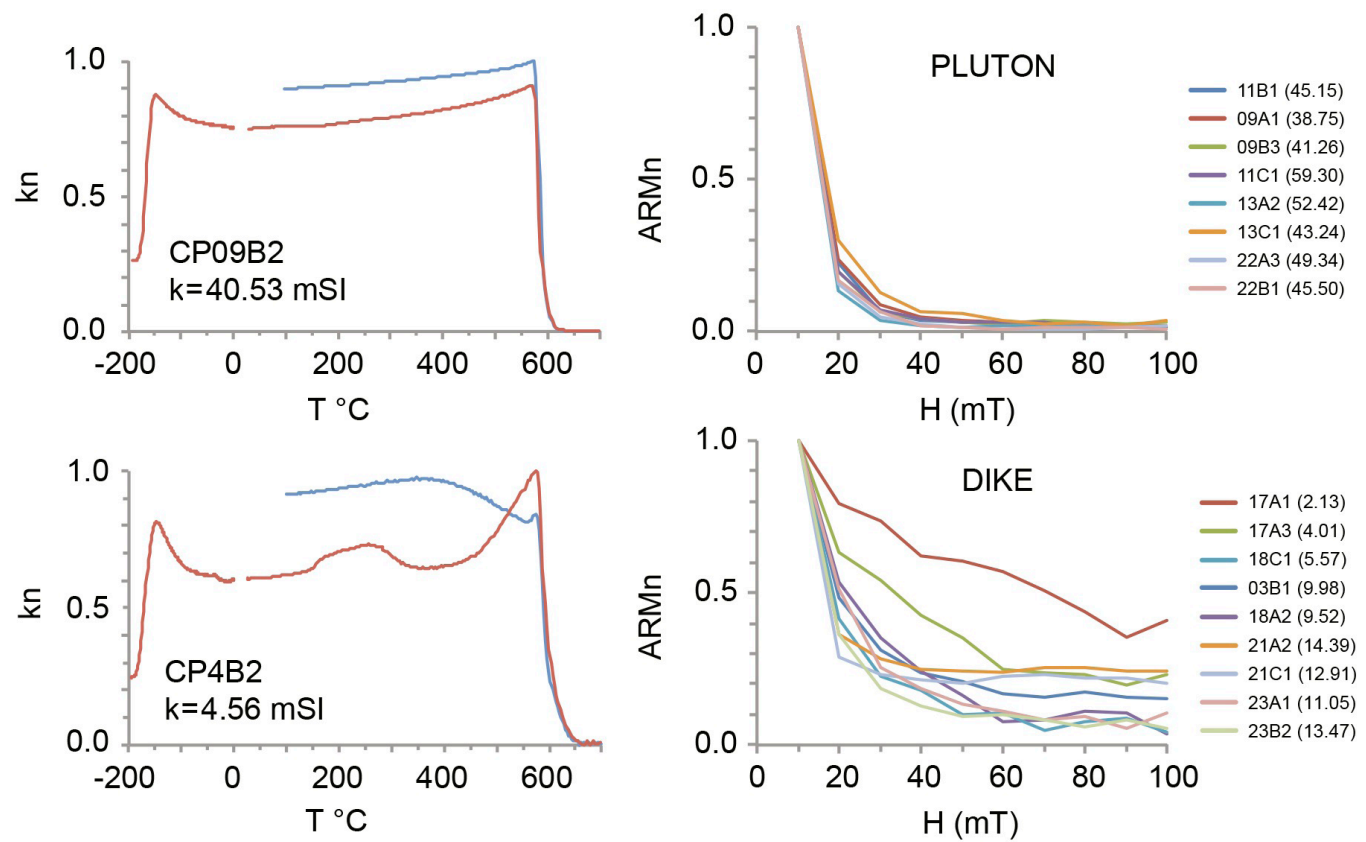

FIG. 5. Left side: dependence of magnetic susceptibility $(\mathrm{kn})$ with temperature $\left(\mathrm{T}^{\circ} \mathrm{C}\right)$ for representative samples of the Parashi stock (CP09B2) and related dykes (CP4B2). Right side: coercivity spectra for samples with different susceptibility magnitudes. $\mathrm{H}$ induced field, $A R M n$ normalised anhysteretic remanent magnetisation.

\section{Discussion}

The distinct Verwey transition with a net drop of susceptibility at $580{ }^{\circ} \mathrm{C}$ upon heating (Fig. 5), and the dominance of low-coercivity fractions on the
ARM spectra (Fig. 5) indicate that multidomain, coarse magnetite controls the anisotropy of magnetic susceptibility in the Parashi stock and the associated dykes (Muxworthy and McClelland, 2000; Trindade et al., 2001). Although a few dyke samples displayed 

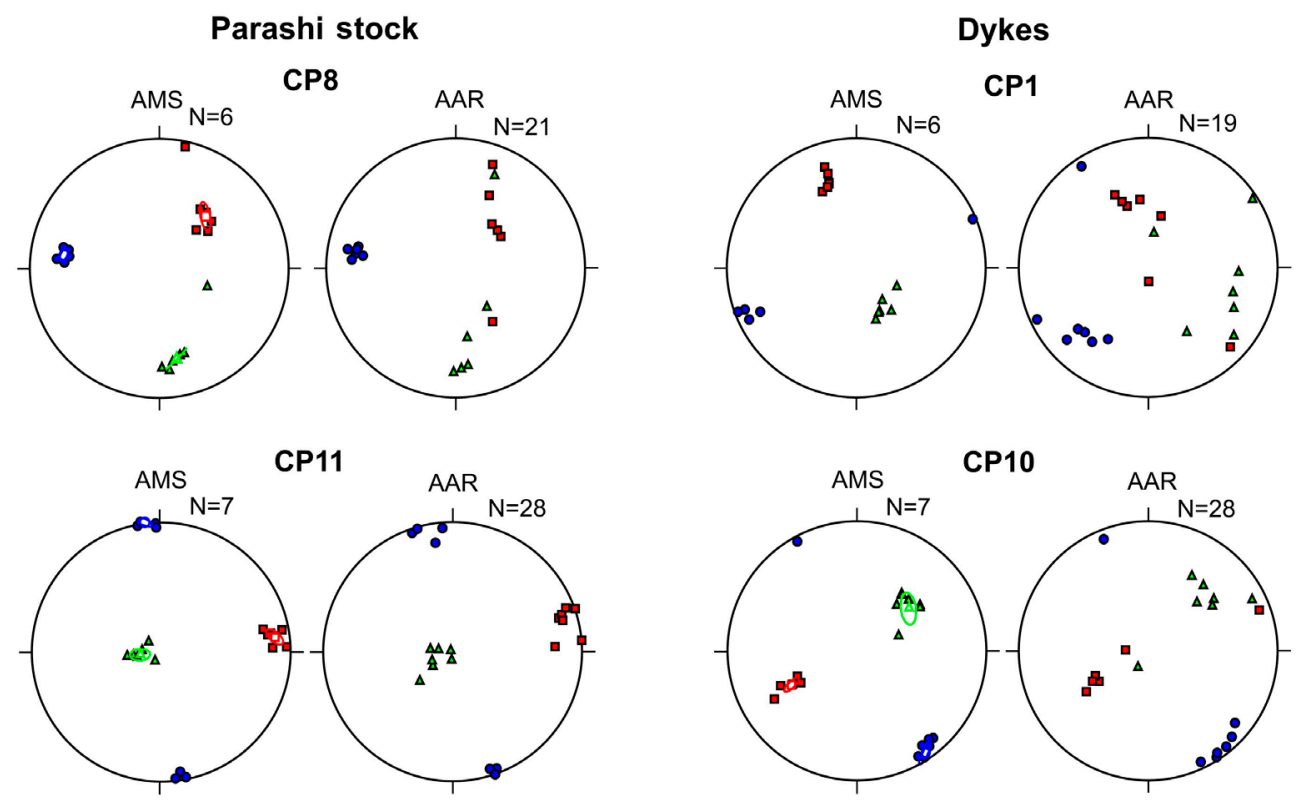

CP22
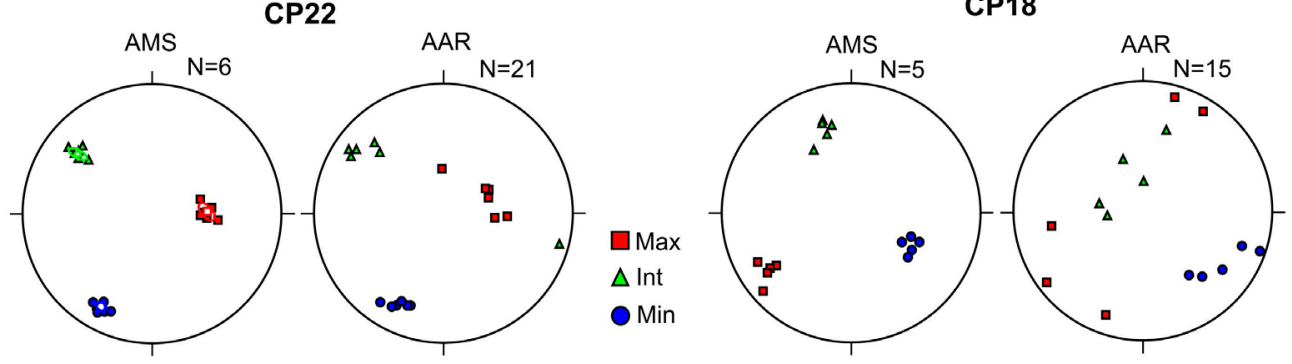

FIG. 6. Stereograms (lower hemisphere) of the principal directions of AMS and AAR for selected samples from the Parashi stock and dykes.

lower susceptibilities and $\mathrm{k}-\mathrm{T}$ curves that suggest minor contributions of possibly hematite and/or maghemite, the consistency between the AMS and AAR indicates these phases do not modify the magnetic fabric orientation. Late magmatic-hydrothermal fluids associated with the emplacement of the dykes might account for the crystallisation of the secondary magnetic phases, such as hematite which, in some cases, can partially replace the coarse magnetite. Fine magnetite particles, which could have been formed by hydrothermal fluids and hence might provide anomalous fabrics, are precluded due to the similarity between the AMS and AAR principal directions (Fig. 6; Rochette et al., 1992). Magnetic fabrics recorded in the Parashi magmatic complex are therefore considered to depend on the preferred orientation of the magnetite grains which, according to comparative studies with silicate fabrics in granitic rocks, closely approximate the magmatic fabric fairly well (Archanjo et al., 1995; Salazar et al., 2008; Arbaret et al., 2013; Schopa et al., 2015).

Foliations defined by the AMS data, combined with the planar structures measured within the pluton, are consistent with a concentric planar fabric acquired during the emplacement, possibly resulting from the action of internal body (ascensional) forces. A similar fabric type was recorded in experimental models simulating the upward extrusion of lava domes (Harnett et al., 2018). The concentric fabric would be formed by drag forces between the wall rocks and a confined volume of magma moving upward, perhaps being enhanced by helical magma movements that arose when the flow velocity in the inner part of the conduit was higher than in its outer part (Fowler, 1996; 


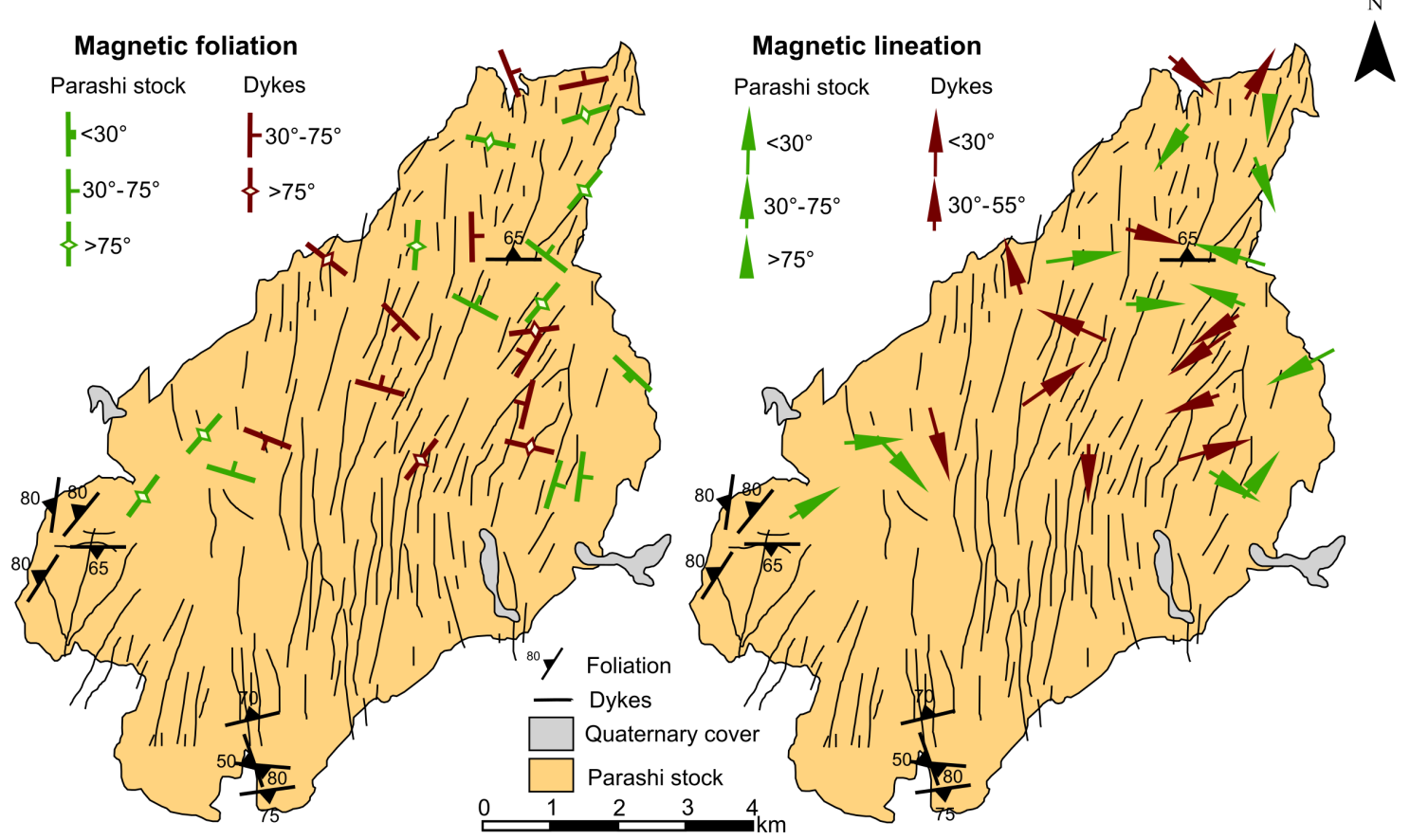

FIG. 7. Magnetic fabric (foliation and lineation) showing a map with the foliation (left) and lineation (right) of samples from the Parashi stock and dykes. Field structural data (in black) are also included within the pluton's map.
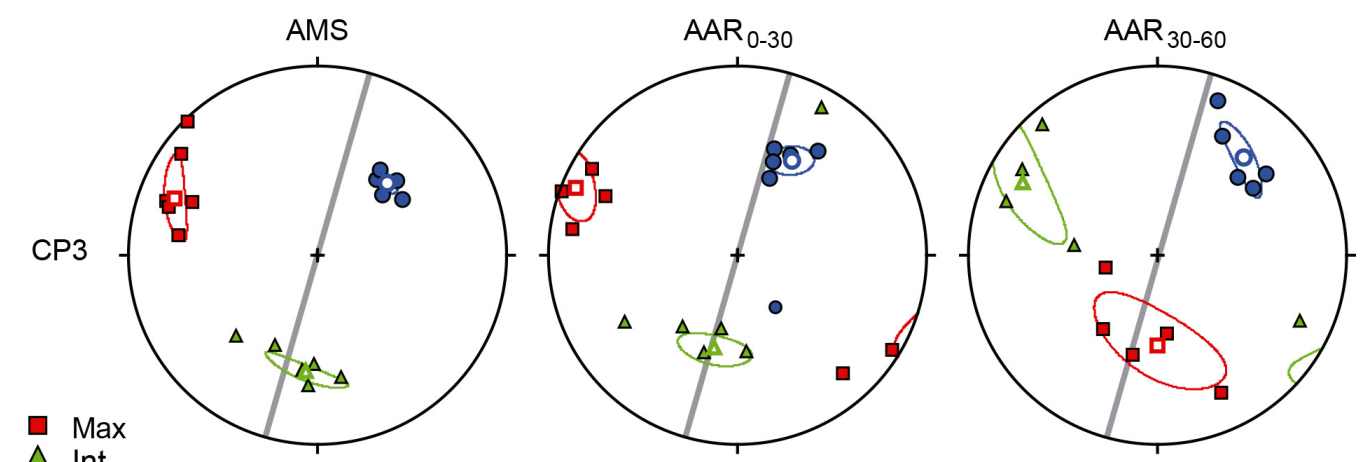

$\triangle$ Int

Min
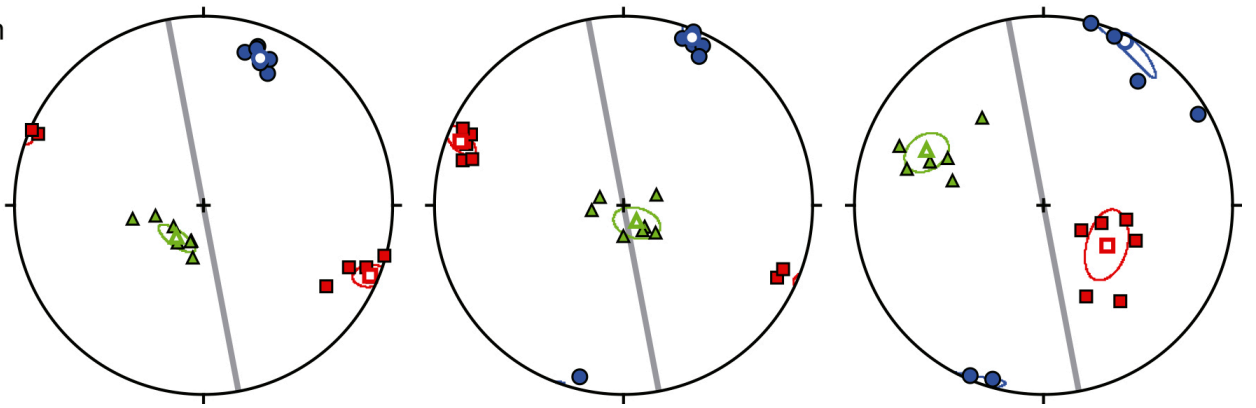

FIG. 8. AMS and partial AAR $(0-30 ; 30-60)$ for dykes showing an inverse-type fabric (CP3 and CP23), where the grey line represents the dyke trend measured in the field. 
Trubac et al., 2009). The differential displacement of the magma would additionally be able to deform the magmatic microstructures at high temperature, as shown by the typical fabrics of the Parashi stock.

The magnetic fabrics of the dykes are typically of normal type, i.e., formed during the crystallisation and cooling of the magma confined between the dyke walls. However, two dykes show an anomalous magnetic fabric (CP3 and CP23) in that the lineation is perpendicular to the walls. As the AAR principal directions are coaxial to the AMS (Fig. 6), the presence of very fine magnetite particles with an inverse fabric is discarded. We can speculate, therefore, that the magnetic lineation would record the direction of the brittle opening of the dyke wall, with the magnetite crystals growing parallel to the local extension direction of the dyke.

Evidence for the shallow emplacement of the stock is attested by the intrusion of sub-volcanic felsic dyke swarm and wall rock structures that are partially truncated at the stock margin. Pressure calculations for the Parashi stock were estimated using the available whole-rock geochemistry (Cardona et $a l ., 2014)$ and the Yang (2017) geobarometer. This method is based on the inverse relationship between $\mathrm{SiO}_{2}$ content and pressure of emplacement. Based on geochemical data reported by Cardona et al. (2014), samples with $\mathrm{SiO}_{2}>60 \mathrm{wt} \%$ were chosen. Pressures were obtained after the normative composition was calculated, using the values of quartz $(\mathrm{Qz})$, albite $(\mathrm{Ab})$, and orthoclase (Or). The emplacement depth was calculated from the pressure values, taking into account the relationship of $100 \mathrm{MPa}=2.7 \mathrm{~km}$ (Yang, 2017). The average pressure results (Table 2) of the Parashi stock are $290 \mathrm{MPa}$, corresponding to an emplacement depth of $c a .8 \mathrm{~km}$. This estimate is similar to those reported by Cardona et al. (2011a), who used the $\mathrm{Al}$ in hornblende barometer of Schmidt (1992) and obtained pressures ranging from $230 \mathrm{MPa}$ to $300 \mathrm{MPa}$, or $7 \mathrm{~km}$ to $9 \mathrm{~km}$ of emplacement depth. These barometric data indicate that the Parashi stock emplaced in the shallow crust and that, in the latest stages of crystallisation or after fully crystallised, the stock deformed brittlely and facilitated the emplacement of the dyke, with the magma likely extracted from a reservoir that remained in the deeper crust. The shallow emplacement of the pluton is also attested by the local andalusite hornfels formed next to the contact between the pluton and the low-grade Etpana schist.

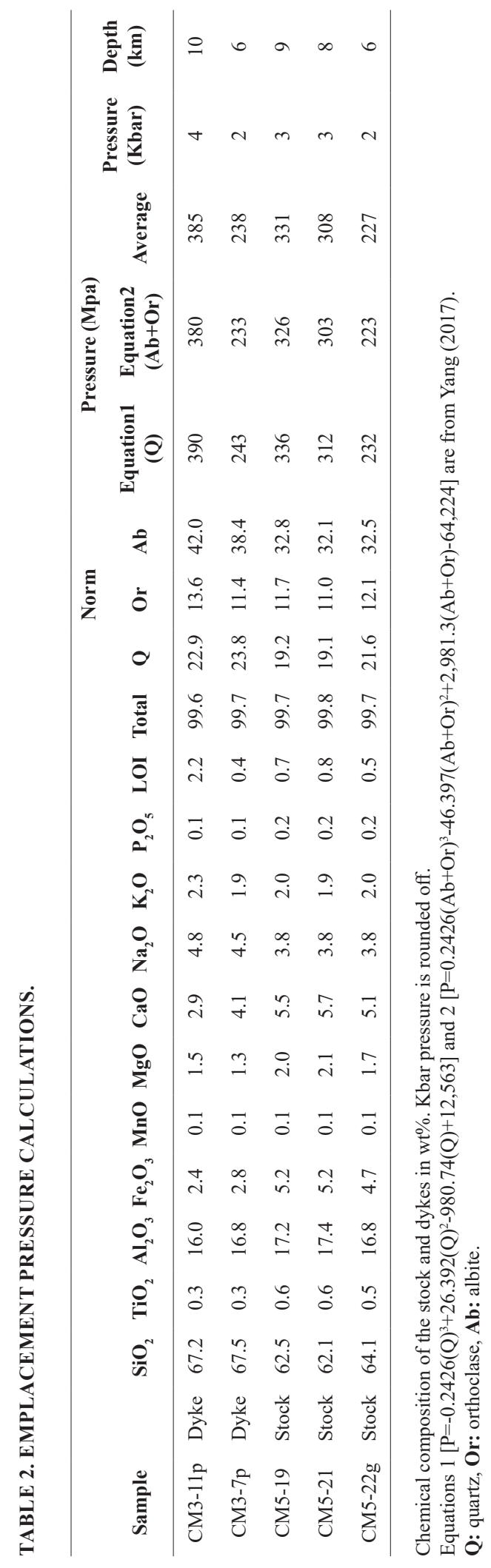


Different palaeogeographic reconstructions, based on regional and local field relations, suggest that the interaction between the Caribbean plate and northern South American plate, since the Late Cretaceous to Palaeocene, has been dominated by oblique convergence and is characterised by continuous changes in the convergence relationship (Pindell et al., 1998; Müeller et al., 1999; Montes et al., 2005, 2010, 2019; Pindell and Keenan, 2009). In the Colombian margin, such interactions began with a Late Cretaceous-Palaeocene arc-continent collisional event, followed by the inception of a new subduction zone after $63 \mathrm{Ma}$, as a consequence of the subduction of the Caribbean plate beneath the northern edge of the South American plate. The subduction appears to have continued until $45 \mathrm{Ma}$, when it switched off, potentially as a consequence of an increase of plate convergence obliquity (Cardona et al., 2010, 2011b; Bayona et al., 2012; Bustamante et al., 2017; Montes et al., 2019). This setting may have created the room needed for the Parashi stock to be emplaced into the shallow crust, where it acquired its concentric fabric, due to the development of the transtensional regime.

According to Cardona et al. (2014), the crystallisation age of the Parashi stock and the dykes is $\sim 51$ to $47 \mathrm{Ma}$, and this time interval overlaps in analytical error. It, therefore, does not permit a clear distinction of the duration of each crystallisation event, although it seems clear that there was a very short time interval between both events based on these ages. As has been described in similar tectonic settings where strong oblique convergence dominated the deformation partitioning (Glazner et al., 1999), dykes can be considered as magmafilled cracks formed during tension associated with a transtensional setting.

In subduction zones, the displacement between the subducting slab and the overthrusted plate is nearly perfectly normal, and some obliqueness makes stress vectors suitable for space creation and pluton emplacement (Saint-Blanquat et al., 1998; Glazner, 1991). In this sense, an oblique convergence of the Caribbean plate with the continental margin of NW South America during Eocene time is considered as a likely tectonic scenario that permitted the emplacement of the shallower, cooler Parashi stock along with the simultaneous opening of E-W cracks that were substantially simultaneous filled by the dyke swarm in a transtensional setting. This setting created the numerous pull-apart-like basin that characterises northern South America in Colombia and Venezuela (Macellari, 1995; Montes et al., 2019).

The emplacement history of the adjacent Santa Marta batholith has been characterised as involving two phases. The first was a major emplacement phase (58-54 Ma) that has been associated with a regional synthetic extensional shear band, related to a NEtrending arc parallel shear plane that was accompanied with shortening (Salazar et al., 2016). The second phase, occurring around $50 \mathrm{Ma}$, was contemporaneous with the emplacement of the Parashi stock (Fig. 9) that recorded the reactivation of the extensional structures. Together, these phases record the switch towards more oblique convergence of the tectonic plates in the northwestern margin of South America.

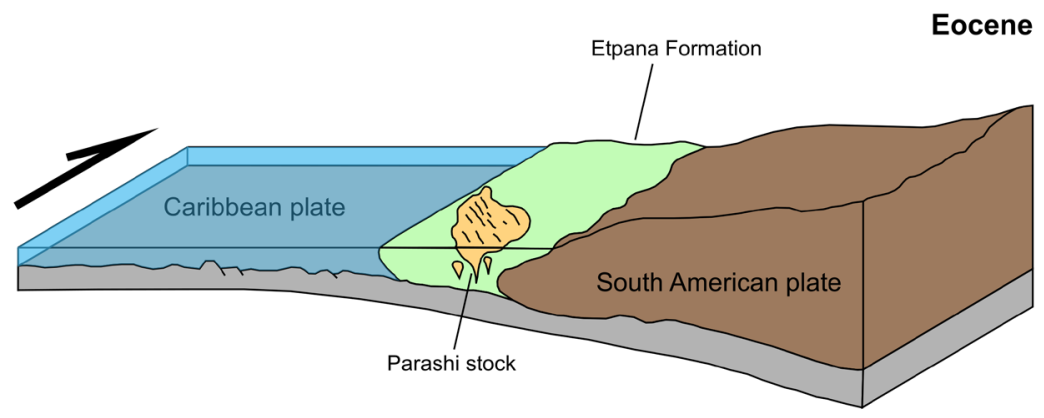

FIG. 9. By the Eocene, the intrusion of the Parashi stock was prompted by a transtensional tectonic regime resulting from the oblique convergence of the Caribbean plate with the continental margin of NW South America. During the final stages of the magma crystallisation, the pluton was able to deform by brittle fracturing, and the dykes intruded. The intrusion occurred when the overriding continental South American plate was deforming mostly by extension (modified from Weber et al., 2010 and Cardona et al., 2014). 


\section{Conclusions}

Low-field AMS and AAR data, micro- and macrostructural evidence and barometric calculations of the Parashi stock emplacement and the related dyke swarm are all consistent with a shallow crustal emplacement (e.g., $<10 \mathrm{~km})$ in a transtensional tectonic setting related to the oblique convergence of the Caribbean and South American plates. This tectonic setting is similar to that proposed for another Eocene arc pluton, the Santa Marta batholith, although the latter records a net component of dextral shearing that was not recorded in the fabric of the Parashi stock. Although both plutons share emplacement mechanisms associated with the oblique convergence of the Caribbean plate, the Parashi stock may have been emplaced in a more stable and cooler crust and may be related to the interruption of the subduction in the Eocene. The magnetic foliation of the stock tends to show a concentric organization attributed to the differential upward movement of the magma. The dykes, in turn, were emplaced in the final stages of the magma crystallisation when the pluton was able to deform by brittle fracturing, which is consistent with the crystallisation ages determined for the stock and dykes.

\section{Acknowledgements}

This research was made possible by the funds received from the Fundación para la Promoción de la Investigación y la Tecnología del Banco de la República de Colombia (Project $\mathrm{N}^{\circ}$ 3171). C.B acknowledges D. Ramírez for his support during field work, D. Brandt and G. Moreira for their assistance at the Laboratorio de Paleomagnetismo (IAG-USP), L.G. Viegas for his help during sample analyses, L. Chavarria for her assistance with the thermobarometric calculations and E. Bustamante for his support during the core sampling. The early review made by J. Geissman helped to improve the quality of this manuscript. L. Alva, W. Vivallo and an anonymous reviewer are acknowledged for their constructive reviews that help to improve the manuscript. This is a contribution to the Semillero de Investigación en Mineralogía y Petrología (U. EAFIT).

\section{References}

Arbaret, L.; Launeau, P.; Diot, H.; Sizaret, S. 2013. Magnetic and shape fabrics of magnetite in simple shear flows. Journal of Volcanology and Geothermal Research 249: 25-38.
Archanjo, C.J.; Bouchez, J.L.; Corsini, M.; Vauchez, A. 1994. The Pombal granite pluton: Magnetic fabric, emplacement and relationships with the Brasiliano strike-slip setting of NE Brazil (Paraiba State). Journal of Structural Geology 16 (3): 323-335. doi: 10.1016/01918141(94)90038-8.

Archanjo, C.J.; Launeau, P.; Bouchez, J.L. 1995. Magnetic fabric vs. magnetite and biotite shape fabrics of the magnetite-bearing granite pluton of Gameleiras (Northeast Brazil). Physics of the Earth and Planetary Interiors 89 (1-2): 63-75.

Baquero, M.; Montes, C.; Bayona, G.A. 2014. Attributebased processing of lineament data: an example from Cesar-Rancheria and neighbor provinces in Colombia. In Earth Resources and Environmental Remote Sensing/ GIS Applications V (Michel, U.; Schulz, K.; Ehlers, M.; Nikolakopoulos, K.G.; Civco, D.; editors). International Society for Optics and Photonics, Proceedings of SPIE 9245-92450F. doi: 10.1117/12.2067447.

Bayona, G.; Cardona, A.; Jaramillo, C.; Mora, A.; Montes, C.; Valencia, V.; Ayala, C.; Montenegro, O.; IbáñezMejía, M. 2012. Early Paleogene magmatism in the northern Andes: insights on the effects of oceanic plateau-continent convergence. Earth and Planetary Science Letters 331-332: 97-111. doi.10.1016/j. eps1.2012,03.015.

Bayona, G.; Cardona, A.; Jaramillo, C.; Mora, A.; Montes, C.; Caballero, V.; Mahecha, H.; Lamus, F.; Montenegro, O.; Jiménez, G.; Mesa, A; Valencia, V. 2013. Onset of fault reactivation in the Eastern Cordillera of Colombia and proximal Llanos Basin; response to CaribbeanSouth American convergence in early Palaeogene time. Geological Society of London, Special Publications 377 (1): 285-314.

Borradaile, G.J.; Jackson, M. 2004. Anisotropy of Magnetic Susceptibility (AMS): magnetic petrofabric of deformed rocks. In Magnetic Fabric: Methods and Applications (Martín-Hernández, F.; Lunenburg, C.M.; Aubourg, C.; Jackson, M.; editors). Geological Society of London, Special Publication 238: 299-360.

Boschman, L.M.; van Hinsbergen, D.J.; Torsvik, T.H.; Spakman, W.; Pindell, J.L. 2014. Kinematic reconstruction of the Caribbean region since the Early Jurassic. Earth-Science Reviews 138: 102-136.

Bouchez, J.L. 1997. Granite is never isotropic: an introduction to AMS studies in granitic rocks. In Granite: from segregation of melt to emplacement fabrics (Bouchez, J.L.; Hutton, D.H.W.; Stephens, W.E.; editors). Springer Science, Business Media B.V.: 95-112. Dordrecht. 
Burke, K.; Cooper, C.; Dewey, J.F.; Mann, P.; Pindell, J.L. 1984. Caribbean tectonics and relative plate motions. Geological Society of America, Memoirs 162: 31-63.

Burton-Johnson, A.; Macpherson, C.G.; Muraszko, J.R.; Harrison, R.J.; Jordan, T.A. 2019. Tectonic strain recorded by magnetic fabrics (AMS) in plutons, including Mt Kinabalu, Borneo: A tool to explore past tectonic regimes and syn-magmatic deformation. Journal of Structural Geology 119: 50-60.

Bustamante, C.; Cardona, A.; Saldarriaga, M.; García-Casco, A.; Valencia, V.; Weber, M. 2009. Metamorfismo de los esquistos verdes y anfibolitas pertenecientes a los Esquistos de Santa Marta, Sierra Nevada de Santa Marta (Colombia): ¿registro de la colisión entre el Arco Caribe y la margen Suramericana? Boletín de Ciencias de la Tierra 25: 7-26.

Bustamante, C.; Cardona, A.; Archanjo, C.J.; Bayona, G.; Lara, M.; Valencia, V. 2017. Geochemistry and isotopic signatures of Paleogene plutonic and detrital rocks of the Northern Andes of Colombia: A record of postcollisional arc magmatism. Lithos 277: 199-209.

Cardona, A.; Valencia, V.; Bayona, G.; Jaramillo, C.; Ojeda, G.; Ruiz, J. 2009. U/Pb LA-MC-ICP-MS zircon geochronology and geochemistry from a postcollisional biotite granite of the Baja Guajira basin, Colombia: Implications for Late Cretaceous and Neogene Caribbean-South America tectonics. The Journal of Geology 117 (6): 685-692.

Cardona, A.; Valencia, V.; Bustamante, C.; García-Casco, A.; Ojeda, G.; Ruiz, J.; Saldarriaga, M.; Weber, M. 2010. Tectonomagmatic setting and provenance of the Santa Marta Schists, Northern Colombia: insights on the growth and approach of Cretaceous Caribbean oceanic terranes to the South American continent. Journal of South American Earth Sciences 29 (4): 784-804.

Cardona, A.; Valencia, V.; Bayona, G.; Duque, J.; Ducea, M.; Gehrels, G.; Jaramillo, C.; Montes, C.; Ojeda, G.; Ruiz, J. 2011a. Early subduction orogeny in the Northern Andes: Turonian to Eocene magmatic and provenance record in the Santa Marta massif and Rancheria Basin, Northern Colombia. Terra Nova 23 (1): 26-34. doi: 10.1111/j.1365-3121.2010.00979.x.

Cardona, A.; Valencia, V.; Weber, M.; Duque, J.; Montes, C.; Ojeda, G.; Reiners, P.; Domanik, K.; Nicolescu, S.; Villagómez, D. 2011b. Transient Cenozoic tectonic stages in the southern margin of the Caribbean plate: $\mathrm{U}-\mathrm{Th} / \mathrm{He}$ thermochronological constraints from Eocene plutonic rocks in the Santa Marta massif and Serrania de Jarara, northern Colombia. Geologica Acta 9 (3-4): 445-466. doi: 10.1344/105.000001739.
Cardona, A.; Weber, M.; Cordani, U.; Valencia, V.; Bustamante, C.; Montes, C.; Cordani, U.; Muñoz, C.M. 2014. Geochronology and geochemistry of the Parashi granitoid, NE Colombia: Tectonic implication of short-lived Early Eocene plutonism along the SE Caribbean margin. Journal of South American Earth Sciences 50: 75-92.

Cardona, A.; León, S.; Jaramillo, C.; Montes, C.; Valencia, V.; Vanegas, J.; Bustamante, C.; Echeverri, S. 2018. The Paleogene arcs of the northern Andes of Colombia and Panama: Insights on plate kinematic implications from new and existing geochemical, geochronological and isotopic data. Tectonophysics 749: 88-103.

Clemens, J.D.; Benn, K. 2010. Anatomy, emplacement and evolution of a shallow-level, post-tectonic laccolith: The Mt Disappointment pluton, SE Australia. Geological Society Journal 167 (5): 915-941. doi: 10,001676492009.

Cruden, A.R. 1998. On the emplacement of tabular granites. Journal of the Geological Society London 155 (5): 853-862.

Duque-Caro, H. 1979. Major structural elements and evolution of northwestern Colombia. In Geological and geophysical investigations of continental margin (Watkins, J.S.; Montadert, L.; Dickerson, P.W.; editors). American Association of Petroleum Geologists 29, Memoir: 329-351.

Duque-Trujillo, J.F.; Bustamante, C.; Solari, L.; GómezMafla, Á.; Toro-Villegas, G.; Hoyos, S. 2019a. Reviewing the Antioquia batholith and satellite bodies: a record of Late Cretaceous to Eocene syn-to postcollisional arc magmatism in the Central Cordillera of Colombia. Andean Geology 46 (1): 82-101. doi: 10.5027/andgeoV46n1-3120.

Duque-Trujillo, J.F.; Orozco-Esquivel, T.; Sánchez, C.J.; Cárdenas-Rozo, A.L. 2019b. Paleogene Magmatism of the Maracaibo Block and Its Tectonic Significance. In Geology and Tectonics of Northwestern South America: Frontiers in Earth Sciences (Cediel, F.; Shaw, R.P.; editors). Springer: 551-601. Cham.

Escalona, A.; Mann, P. 2003. Three-dimensional structural architecture and evolution of the Eocene pull-apart basin, central Maracaibo basin, Venezuela. Marine and Petroleum Geology 20 (2): 141-161.

Fowler, T.J. 1996. The properties and geological environments of helicoids: axially symmetric surfaces in torsional and non-torsional deformations. Journal of Structural Geology 18 (4): 505-517.

Gehring, A.U.; Fischer, H.; Louvel, M.; Kunze, K.; Weidler, P.G. 2009. High temperature stability of 
natural maghemite: a magnetic and spectroscopic study. Geophysical Journal International 179 (3): 1361-1371. doi: 10.1111/j.1365-246X.2009.04348.x.

Glazner, A.F. 1991. Plutonism, oblique subduction, and continental growth: An example from the Mesozoic of California. Geology 19 (8): 784-786. doi: 10.1130/0091-7613(1991)019<0784:POSACG>2.3.CO;2.

Glazner, A.F.; Bartley, J.M.; Carl, B.S. 1999. Oblique opening and noncoaxial emplacement of the Jurassic Independence dike swarm, California. Journal of Structural Geology 21 (10): 1275-1283. doi: 10.1016/ S0191-8141(99)00090-5.

Harnett, C.E.; Thomas, M.E.; Purvance, M.D.; Neuberg, J. 2018. Using a discrete element approach to model lava dome emplacementand collapse. Journal of Volcanology and Geothermal Research 359: 68-77. doi: 10.1016/j. jvolgeores.2018.06.017.

Hrouda, F. 1982. Magnetic anisotropy of rocks and its application in geology and geophysics. Geophysical Surveys 5 (1): 37-82. doi: 10.1007/BF01450244.

Hughes, R.A.; Pilatasig, L.F. 2002. Cretaceous and Tertiary terrane accretion in the Cordillera Occidental of the Andes of Ecuador. Tectonophysics 345 (1-4): 29-48. doi: 10.1016/S0040-1951(01)00205-0.

Jackson, M. 1991. Anisotropy of magnetic remanence: a brief review of mineralogical sources, physical origins and geological applications, and comparison with susceptibility anisotropy. Pure and Applied Geophysics 136 (1): 1-28.

Jackson, M.; Gruber, W.; Marvin, J.; Banerjee, S.K. 1988. Partial anhysteretic remanence and its anisotropy: applications and grainsize-dependence. Geophysical Research Letters 15 (5): 440-443.

Jelinek, V. 1978. Statistical processing of anisotropy of magnetic susceptibility measured on groups of specimens. Studia Geophysica et Geodaetica 22 (1): 50-62. doi: 10.1007/BF01613632.

Kerr, A.C. 2014. Oceanic Plateaus. In Treatise on Geochemistry: The Crust (Holland, H.D.; Turekian, K.K.; editors). Elsevier: 631-667. Amsterdam. doi: 10.1016/B978-0-08-095975-7.00320-X.

Kerr, A.C.; Marriner, G.F.; Tarney, J.; Nivia, A.; Saunders, A.D.; Thirlwall, M.F.; Sinton, C.W. 1997. Cretaceous basaltic terranes in western Colombia: elemental, chronological and Sr-Nd constraints on petrogenesis. Journal of Petrology 38 (6): 677-702. doi: 10.1093/ petroj/38.6.677.

Lockwood, J.P. 1965. Geology of the Serranía de Jarara area, Guajira Península, Colombia. Ph.D. Thesis (Unpublished), Princeton University: 237 p.
Lugo, J.; Mann, P. 1995. Jurassic-Eocene tectonic evolution of Maracaibo basin, Venezuela. In Petroleum Basins of South America (Tankard, A.J.; Suárez-Soruco, R.; Welsink, H.J.; editors). AAPG Special Volumes 62: 699-725.

Macellari, C.E. 1995. Cenozoic Sedimentation and Tectonics of the Southwestern Caribbean Pull-Apart Basin, Venezuela and Colombia. In Petroleum Basins of South America (Tankard, A.J.; Suárez-Soruco, R.; Welsink, H.J.; editors). AAPG Memoir 62: 757-780.

Mamtani, M.A.; Bhatt, S.; Rana, V.; Sen, K.; Mondal, T.K. 2019. Application of anisotropy of magnetic susceptibility (AMS) in understanding regional deformation, fabric development and granite emplacement: examples from Indian cratons. Geological Society of London, Special Publications 489: SP489-2019. doi: 10.1144/ SP489-2019-292.

Magee, C.; Stevenson, C.; O'driscoll, B.; Schofield, N.; McDermott, K. 2012. An alternative emplacement model for the classic Ardnamurchan cone sheet swarm, NW Scotland, involving lateral magma supply via regional dykes. Journal of Structural Geology 43: 73-91. doi: 10.1016/j.jsg.2012.08.004.

Martínez, L.F.; Zuluaga, C.A. 2010. Thermal modeling of pluton emplacement and associated contact metamorphism: Parashi stock emplacement in the Serranía de Jarara (Alta Guajira, Colombia). Earth Sciences Research Journal 14 (2): 145-152.

McCabe, C.; Jackson, M.; Ellwood, B.B. 1985. Magnetic anisotropy in the Trenton limestone: results of a new technique, anisotropy of anhysteretic susceptibility. Geophysical Research Letters 12 (6): 333-336.

Montes, C.; Hatcher, R.D.; Restrepo-Pace, P. 2005. Tectonic reconstruction of the northern Andean blocks: oblique convergence and rotations derived from the kinematics of the Piedras-Girardot area, Colombia. Tectonophysics 399 (1-4): 221-250. doi: 10.1016/j.tecto.2004.12.024.

Montes, C.; Guzmán, G.; Bayona, G.; Cardona, A.; Valencia, V. 2010. Clockwise rotation of the Santa Marta massif and simultaneous Paleogene to Neogene deformation of the Plato-San Jorge and Cesar-Ranchería basins. Journal of South American Earth Sciences 29 (4): 832-848. doi: 10.1016/j.jsames.2009.07.010.

Montes, C.; Rodríguez-Corcho, A.F.; Bayona, G.; Hoyos, N.; Zapata, S.; Cardona, A. 2019. Continental margin response to multiple arc-continent collisions: The northern Andes-Caribbean margin. EarthScience Reviews 198: 102903. doi: 10.1016/j. earscirev.2019.102903. 
Müeller, R.D.; Royer, J.Y.; Cande, S.C.; Roest, W.R.; Maschenkov, S. 1999. New constraints on the late cretaceous/tertiary plate tectonic evolution of the caribbean. In Caribbean Basins (Mann, P.; editor). Sedimentary Basins of the World, Book Series 4, Elsevier Science:33-59.

Muessig, K.W. 1984. Structure and Cenozoic tectonics of the Falcón Basin, Venezuela, and adjacent areas. Geological Society of America, Memoirs 162: 217-230.

Muxworthy, A.R.; McClelland, E. 2000. Review of the low-temperature magnetic properties of magnetite from a rock magnetic perspective. Geophysical Journal International 140 (1): 101-114.

Nova, G.; Chaparro, G.A.B.; Silva-Tamayo, J.C.; Cardona, A.; Rapalini, A.; Cortés, P.C.M.; Eisenhauer, A.; Dussan, K.T.; Valencia, V.; Ramírez, V.; Montes, C. 2019. Jurassic break-up of the Peri-Gondwanan margin in northern Colombia: Basin formation and implications for terrane transfer. Journal of South American Earth Sciences 89: 92-117. doi: 10.1016/j. jsames.2018.11.014.

Pindell, J.; Kennan, L. 2009. Tectonic evolution of the Gulf of Mexico, Caribbean and northern South America in the mantle reference frame: an update. In The geology and evolution of the region between North and South America (James, K.; Lorente, M.A.; Pindell, J.; editors). Geological Society of London Special Publication 328 (1): 1-55.

Pindell, J.L.; Higgs, R.; Dewey, J.F. 1998. Cenozoic palinspastic reconstruction, paleogeographic evolution, and hydrocarbon setting of the northern margin of South America. In Paleogeographic Evolution and Non-glacial Eustasy, northern South America (Pindell, J.L.; Drake, C.L.; editors). Society for Sedimentary Geology, Special Publication 58: 45-86.

Pindell, J.; Kennan, L.; Maresch, W.V.; Stasnek, K.-P.; Draper, G.; Higgs, R. 2005. Plate kinematic and crustal dynamics of circum-Caribbean arc-continent interactions: Tectonics controls on basin development in the Proto-Caribbean margins. In Caribbean-South American plate interactions, Venezuela (Avé Lallemant, H.G.; Sisson, V.B.; editors). Geological Society of America, Special Paper 394: 7-52.

Rochette, P. 1987. Magnetic susceptibility of the rock matrix related to magnetic fabric studies. Journal of Structural Geology 9 (8): 1015-1020.

Rochette, P.; Jackson, M.; Aubourg, C. 1992. Rock magnetism and the interpretation of anisotropy of magnetic susceptibility. Reviews of Geophysics 30 (3): 209-226.
Saint-Blanquat, M.; Tikoff, B.; Teyssier, C.; Vigneresse, J.L. 1998. Transpressional kinematics and magmatic arcs. Geological Society of London, Special Publications 135 (1): 327-340.

Salazar, C.A.; Archanjo, C.J.; Babinski, M.; Liu, D. 2008. Magnetic fabric and zircon U-Pb geochronology of the Itaoca pluton: implications for the Brasiliano deformation of the southern Ribeira belt. Journal of South American Earth Sciences 26 (3): 286-299.

Salazar, C.A.; Bustamante, C.; Archanjo, C.J. 2016. Magnetic fabric (AMS, AAR) of the Santa Marta batholith (northern Colombia) and the shear deformation along the Caribbean Plate margin. Journal of South American Earth Sciences 70: 55-68. doi: 10.1016/j. jsames.2016.04.011.

Schmidt, M.W. 1992. Amphiboles composition in tonalite as a function of pressure: an experimental calibration of the $\mathrm{Al}$ in hornblende barometer. Contributions to Mineralogy and Petrology 110 (2-3): 304-310.

Schopa, A.; Floess, D.; Saint-Blanquat, M.; Annen, C.; Launeau, P. 2015. The relation between magnetite and silicate fabric in granitoids of the Adamello Batholith. Tectonophysics 642: 1-15.

Siegesmund, S.; Becker, J.K. 2000. Emplacement of the Ardara pluton (Ireland): new constraints from magnetic fabrics, rock fabrics and age dating. International Journal of Earth Sciences 89 (2): 307-327.

Stephenson, A.; Sadikun, S.T.; Potter, D.K. 1986. A theoretical and experimental comparison of the anisotropies of magnetic susceptibility and remanence in rocks and minerals. Geophysical Journal International 84 (1): 185-200.

Tomek, F.; Zák, J.; Verner, K.; Holub, F.V.; Sláma, J.; Paterson, S.R.; Memeti, V. 2017. Mineral fabrics in high-level intrusions recording crustal strain and volcano-tectonic interactions: the Shellenbarger pluton, Sierra Nevada, California. Journal of the Geological Society 174 (2): 193-208. doi: 10.1144/jgs2015-151.

Trindade, R.I.F.; Bouchez, J.L.; Bolle, O.; Nedelec, A.; Peschler, A.; Poitrasson, F. 2001. Secondary fabrics revealed by remanence anisotropy: methodological study and examples from plutonic rocks. Geophysical Journal International 147 (2): 310-318. doi: 10.1046/j.0956540x.2001.01529.x.

Trubac, J.; Zák, J.; Chlupácová, M.; Janousek, V. 2009. Magnetic fabric of the Ríčany granite, Bohemian Massif: A record of helical magma flow? Journal of Volcanology and Geothermal Research 181 (1-2): 25-34.

Trubac, J.; Zák, J.; Chlupácová, M.; Janousek, V. 2014. Magnetic fabric and modeled strain distribution in the 
head of a nested granite diapir, the Melechov pluton, Bohemian Massif. Journal of Structural Geology 66: 271-283. doi: 10.1016/j.jsg.2014.05.015.

Vallejo, C.; Spikings, R.A.; Winkler, W.; Luzieux, L.; Chew, D.; Page, L. 2006. The early interaction between the Caribbean Plateau and the NW South American Plate. Terra Nova 18 (4): 264-269. doi: 10.1111/j.13653121.2006.00688.x.

Vernon, R. 2000. Review of microstructural evidence of magmatic and solid-state flow. Visual Geosciences 5 (2): 1-23. doi: 10.1007/s10069-000-0002-3.

Weber, M.B.I.; Cardona, A.; Paniagua, F.; Cordani, U.; Sepúlveda, L.; Wilson, R. 2009. The Cabo de la Vela Mafic-Ultramafic Complex, Northeastern Colombian Caribbean region: a record of multistage evolution of a Late Cretaceous intra-oceanic arc. Geological Society of London, Special Publications 28 (1): 549-568.
Weber, M.; Cardona, A.; Valencia, V.; García-Casco, A.; Tobón, M.; Zapata, S. 2010. U/Pb detrital zircon provenance from Late Cretaceous metamorphic units of the Guajira Peninsula, Colombia: tectonic implications on the collision between the Caribbean arc and the South American margin. Journal of South American Earth Sciences 29: 805-816. doi: 10.1016/j. jsames.2009.10.004.

Yang, X.M. 2017. Estimation of crystallization pressure of granite intrusions. Lithos 286: 324-329. doi:10.1016/j. lithos.2017,06.018.

Zapata, S.; Weber, M.; Cardona, A.; Valencia, V.; Guzmán, G.; Tobón, M. 2010. Provenance of Oligocene conglomerates and associated sandstone from the Siamaná Formation, Serranía de Jarara, Guajira, Colombia: relations with Oligocene Caribbean tectonics and basin formation. Boletín de Ciencias de la Tierra 27: 7-24.

Manuscript received: April 26, 2020; revised/accepted: August 26, 2020; available online: January 29, 2021. 